\title{
Representasi Dakwah Dalam Komik
}

\author{
Ulil Inayah $^{* 1}$, Saeful Anwar ${ }^{1}$, Bahrudin $^{2}$ \\ 1 Jurusan Pengembangan Masyarakat Islam, UIN Sunan Gunung Djati, Bandung \\ ${ }^{2}$ Jurusan Ilmu Komunikasi, UIN Sunan Gunung Djati, Bandung \\ *Email:ulilinayab024@gmail.com
}

\begin{abstract}
ABSTRAK
Dakwah tidak hanya dilakukan menggunakan media komunikasi langsung. Dengan berkembangan zaman kegiatan dakwah dapat disampaikan melalui media cetak, salah satunya menggunakan komik. Dengan adanya komik yang bertemakan religi tidak hanya untuk menghibur pembacanya melainkan untuk menyampaikan informasi-informasi yang sangat bermanfaat dan sangat mendidik, saat ini untuk menemukan komik yang bertemakan religi sangat gampang ditemukan salah satunya Komik 99 Pesan Nabi karya Vbi_Djenggotten. Dalam komik tersebut terdapat cerita yang ringan agar dapat diteapkan pada kehidupan sehari-hari. Bertujuan untuk mengetahui kategorisasi, sistematika dan himbauan pesan dakwah meliputi pesan akhlak, aqidah serta syari'ah yang terdapat pada komik tersebut. Adapun metode yang digunakan dalam penelitian ini adalah menggunakan metode analisis isi dengan menggunakan coding, setelah menganalisis penelitian dapat diketahui bahwa pesan-pesan dakwah pada Komik 99 Pesan Nabi sebanyak 99 pesan, yang dikategorisasikan menjadi tiga yaitu akhak, aqidah dan syari'ah. Di dalam sistematika pesan mengandung empat bagian yaitu pengantar, pernyataan, argumen, dan kesimpulan. Untuk himbauan pesan mengandung himbauan rasional mengandung 6 pesan, himbauan emosional mengandung 4 pesan, himbauan taut mengandung 51 pesan, himbauan ganjaran mengandung 23 pesan, dan himbauan motivasional mengandung 15 pesan.
\end{abstract}

Kata Kunci : Komik; Analisis; Representasi Dakwah

\section{ABSTRACT}

$D a^{\prime} w a h$ is not only done using direct communication media. With the development of the era of da'wah activities can be delivered through print media, one of which uses comics. With the existence of religious-themed comics not only to entertain the reader but to convey information that is very useful and very educational, now to find religious-themed comics is easy to find, one of them is the Message of the Prophet 99 by Vbi_Djenggotten. In the comic there are light 
stories that can be applied to everyday life. Aiming to find out the categorization, systematics and appeals of da'wah messages including moral, aqeedah and syari'ah messages contained in the comic. The method used in this study is to use the content analysis method using coding, after analyzing the research it can be seen that the message of preaching on the 99 Messages of the Prophet's Message as many as 99 messages, which are categorized into three, namely akhak, aqeedah and syari'ah. In systematics the message contains four parts, namely introduction, statement, argument, and conclusion. For appeals to messages containing rational appeal containing 6 messages, emotional appeals containing 4 messages, appeals for links containing 51 messages, reward calls containing 23 messages, and motivational appeals containing 15 messages.

Keywords : Comic; Analysis; Representation of Da'wah

\section{PENDAHULUAN}

Islam adalah agama yang mewajibkan seluruh umatnya untuk melakukan kebaikan dan mencegah kemungkaran. Kewajiban ini dilakukan secara bersamaan sehingga bisa mengubah prilaku manusia berdasarkan pengetahuan dan sikap yang benar untuk beribadah kepada allah. Begitupun dengan dakwah adalah mengajak manusia untuk memenuhi perintah Allah dan meninggalkan larangannya supaya mendapatkan kebahagiaan dunia akhirat.

Dakwah merupaan sebagai ajakan bagi umat manusia, orang islam khususnya, baik secara lisan tulisan ataupun perbuatan (Hajir Tajiri, 2015: 16). Dilihat dari segi bahasa dakwah berarti panggilan, seruan atau ajakan. Jadi dakwah pada dasarnya adalah upaya seseorang untuk menyadarkan atau mengajaksesama untuk menumbuhkan kecintaannya terhadap islam atau menyadarkan orang-orang yang masih belum memahami Islam lebih dalam dan menumbuhkan ketertarikan kepada agama Islam. Mengajak seseorang untuk memeluk islam sama dengan dia berupaya untuk menumbuhkan kecintaan seseorang dan ketertarikan pada agama Islam.

Dakwah Islam tidak hanya terbatas pada aktifitas lisan saja, tetapi mencangkup seluruh aktifitas lisan atau pembuatan yang ditujukan dalam rangka menumbuhkan kecenderungan dan ketertarikan pada Islam (Ahmad Mahmud, 2011:13). Dakwah adalah kewajiban, sekaligus ibadah bagi umat muslim yang bisa mengantarkan sesamanya untuk dekat denga Allah. Dakwah juga mengajarkan seseorang bahwa kedudukannya di hadapan Allah sangat tinggi dibanding dengan makhluk lainnya. Allah akan mengangkat kedudukannya di dunia maupun di akhirat.

Dakwah islam saat ini tidak hanya dengan media mimbar seperti ceramah dan pengajian yang masih menggunakan media komunikasi tutur kata, pengguna media komunikasi modern sesuai dengan tarif perkembangan daya pikir manusia agar dakwah islam lebih cepat diterima pada sasarannya dengan harapan akan merubah sikap dan tingkah laku seseorang pada kehidupan sehari-hari. 
Berdasarkan dengan penelitian ini, peneliti memilih bentuk kegiatan dakwah yang mempunyai korelasi dengan dakwah melalui tulisan. Dalam pelaksanaan dakwah harus mengikuti pada arah perkembangan zaman, berdakwah tidak hanya dilakukan diatas mimbar tetapi dakwah bisa dilakukan melewati media apa saja.

Media dakwah merupakan salah satu tambahan dari kegiatan dakwah, dengan berkembangan zaman, media yang dijadikan perantara untuk berdakwah yaitu media cetak, dan media cetak banyak bentuknya, ada buku, majalah, tabloid, koran, komik dan sebagainya. Dengan adanya media yang sangat banyak maka da'i harus kretif bisa memilih media yang efektif untuk mencapai tujuan kegiatan dakwah dengan menggunakan media massa seperti itu dakwah akan memiliki mad'u sesuai sasaran akan memiliki kekekalan, karena media cetak bisa dibaca bertahun-tahun walaupun penulisnya sudah meninggal. Begitupula dengan komik, komik adaah salah satu media cetak yang bisa dijadikan perantara berdakwah atau sebagai media dakwah karena pembahasannya lebih luas dibanding dengan media mimbar. Mad'unyapun lebih banyak, tidak terbatas oleh usia sehingga mudah untuk menyebarkan isinya. Saat seseorang membaca sebuah karya tulis yang cocok dengan seleranya maka dia akan tengelam kedalam gagasa, pikiran dan pengalaman yang telah dipaparkan oleh sang penulis (Aep Kusnawan, 2004: 57).

Melihat fenomena sekarang banyak masyarakat memilikiberbagai kesibukan serta waktu yang sedikit untuk mengikuti kajian dakwahyang bersifat tatap muka dengan mubaligh, karena membuthkan waktu yang banyak maka dengan adanya sistem kegiatan dakwah melalui media tulis seperti komik yang bersifat islami atau bersifat religi. Komik salah satu media yang mempunyai ciri khas tersendiri dalam penyampaian pesannya dengan menggunakan gambargambar tidak bergerak yang disusun sedemikian rupa sehingga membentuk alur cerita. Biasanya komik dicetak dan diterbitkan diatas kertas dan dilengkapi dengan gambar dan balon teks. Komik bisa diterbitkan dalam berbagai bentuk, mulai dari strip dalam koran, dimuat dalam majalah hingga berbentuk buku tersendiri.

Sedangkan menurut Will Eisner 1996 komik adalah sebagaian tatanan gambar dan balon kata yang beruntutan dalam sebuah buku komik. Kedudukan komik memegang peran yang sangat penting bag masyaraka, begitupun dengan kegiatan berdakwah akan lebih efektif dan lebih isi yang disampaikan dapat mudah cepat terserap dengan mengajak mad'u untuk melakukan kebaikan lewat media komik, dengan adanya komik dalam ranah komunikasi dan seni visual sudah menjadi viral karena komunikannya dalam komik itu sendiri dan masyarakat pun mampu menerma keberadaan komik sebagai media penyampaian pesan kebaikan dan komik pun menjadi media untuk kegiatan 
dakwah yang unik agar masyarakat tidak bosan dengan kegiatan dakwah yang hanyamenggunakan konsep klasik, komik pun bisa menjadi media penyampaian pesan kebaikan yang unik. Sedangkan Komik 99 Pesan Nabi adalah salah satu komik yang bernuansa islami dan memiliki kesuksesan dalam menyampaikan pesan-pesan positif.

Komik 99 Pesan Nabi adalah salah satu komik yang ditulis oleh Vbi_djenggotten merupakan media cetak yang berkonten islami dengan menampilkan berbagai cerita dan kejadian sehari-hari yang sering dilakukan oleh masyarakat luas dengan cerita yang berdasarkan hadis shahih Bukhari, Muslim, Ahmad dan Abu Daud.

Komik 99 Pesan Nabi dapat memberi dorongan serta motivasi bagi para pembaca serta dapat mengajak dan bahkan menyadarkan pembaca kembali kepada jalan yang lebih baik, selain itu komik ini juga selalu dilengkapi dengan solusi dan cara menyelesaikan permasalahan dari setiap kejadian, dengan cara mengambil dari hadist-hadist, sehinga membuat pembaca tegoyahkan hatinya agar tidak melakukan dan segan untuk mengulang sesuatu yang memang dilarang dalam ajaran Islam.

Hadis-hadis yang digunakan dalam komik ini dituliskan dengan bahasa komik yang asik dalam kisah yang kontekstual dalam kehidupan sehari-hari. Komik ini juga mengandung pesan akidah, syari'ah dan akhlak yang sangat menarik untuk dibaca. Komik ini juga bisa menjadi salah satu cara untuk merubah kebiasaan yang tidak baik dan meningkatan kualitas rohani.

\section{LANDASAN TEORITIS}

Teori yang dijadikan landasan dalam penelitian ini adalah teori dakwah dan tabligh, pesan dakwah. Dakwah menurut Bahasa merupakan mengajak, menyeru, mengundang dan memanggil. Adapun dakwah dalam penelitian ini adalah dengan menggunakan pengertian dakwah khusus yaitu dakwah Islam yang berarti upaya merubah situasi, mendorong, menyeru dan menghimpun manusia kepada ajaran Islam. Upaya tersebut dilakukan dengan bentuk amar ma'ruf nahi munkar, serta upaya itu dimaksudkan agar manusia berbahagia di dunia dan akhirat nanti (Ardi, 2013: 4).

Dalam prosesnya dakwah bukan hanya merupakan fenomena keagamaan saja, namun juga fenomena sosial berlangsung dalam proses sosial memiliki implikasi sosial. Itu artinya selain seorang da'i mengajak dalam praktik keagamaan seperti penerapan ajaran akidah dan syariah namun juga menerapkan ajaran akhlak dalam melakukan kebajikan dan mencegah kemunkaran. Selain dari usaha dalam penyebaran dan pemerataan ajaran agama Islam, dakwah juga merupakan suatu kegiatan dalam proses mengkomunikasikan ajaran agama Allah SW'T yang sesuai dalam al-Qur'an dan as-Sunah. 
Tabligh menurut kamus besar Arab-Indonesia merupakan Bahasa arab yang berasal dari akar kata ballagha, yuballighu, tablighan yang berarti menyampaikan. Sedangkan dalam konteks ajaran Islam, tabligh adalah penyampaian dan pemberitaan tentang ajaran-ajaran Islam kepada umat manusia, yang dengan penyampaian dan pemberitaan tersebut, pemberita terlepas dari kewajiban memberitakan dan pihak penerima berita menjadi terikat dengannya (Sukayat, 2009: 88).

Lebih spesifik dan identik, tabligh meliputi khitabah dan kitabah. Kitabah merupakn tabligh yang dilakukan memlalui media cetak seperti risalah, majalah, artikel, cerpen, sajak, poster, buku, internet, koran dan tulisan-tulisan yang mengandung pesan dakwah merupakan proses penyampaian ajaran Islam. Termasuk juga didalamnya berupa lukisan, kaligrafi, foto yang mengandung pesan-pesan keislaman.

Representasi berasal dari bahsa Inggris, representation, yang berarti perwakilan, gambaran atau penggambaran. Secara sederhana, representasi dapat diartikan sebagai gambaran mengenai suatu hal yang terdapat dalam kehidupan yang digambarkan melalui suatu media (Nawoh Vera, 2014: 96).

Sedangkan representasi menurut Chris Barker adalah konstruksi sosial yang mengharuskan kita mengeksplorasi pembentukan makna tekstual dan menghendaki penyelidikan tentang cara dihasilkannya makna pada beragam konteks. Representasi dan makna budaya memiliki materialitas tertentu. Mereka melekat pada bunyi, prasasti, objek, citra, buku, majalahdan program televisi. Mereka diproduksi, ditampilkan, digunakan dan dipahami dalam konteks sosial tertentu.

Kategorisasi pesan dakwah dapat diambil sesuai dengan ajaran agama Islam yang terdapat dalam al-Qur'an sebagai pedoman hidup manusia, as-Sunah Rasulullah SAW, hasil ijtihad para ulama dan sejarah peradaban Islam. Dalam buku Ilmu Dakwah secara umum materi pesan dakwah diklasifikasikan menjadi tiga kategori yaitu : pesan akhlak, pesan syariah dan pesan aqidah (Samsul Munir Amin, 2013: 90).

Pertama, Alkhlak secara etimologis berarti tingkah laku atau perbuatan. Dan secara terminology akhlak adalah tingkah laku manusia dalam hubungannya dengan alam sekitarnya. Ada juga yang mengartikan secara bahasa perkataan, jamak dalam bahasa arab dari kata khuluk, khulk dalam kamus Al-Munjid berarti budi pekerti, perangai tingkah laku atau tabiat. Didalam da'iratul ma'aruf dikatakan akhlak adalah sifat-sifat manusia yang terdidik (Asmaran As, 2007: 2). dapat diketahui bahwa akhlak ialah sifat-sifat yang dibawa manusia sejak lahir yang tertanam dalam jiwanya dan selalu ada padanya. Sifat itu dapat lahir dalam perbuatan baik, disebut akhlak yang mulia, atau perbuatan buruk, disebut akhlak tercela, sesuai pembinaanya. 
Kedua, Aqidah menurut bahasa berasal dari kata aqada, ya'qidu, aqdan atau aqidatan yang berarti mengingatkan bentuk jama' dari aqidah adalah aqaid yang artinya simpulan atau ikatan iman. Dari kata itu terdapat juga kata I'tiqad yang berarti kepercayaan (Abudin Natta, 1994: 29). Sedangkan Aqidah secara etimologis berarti ikatan atau sangkutan. Secara praktis, aqidah berarti kepercayaan, keyakinan, atau iman. Secara terminologis, yang telah telah dikutip oleh Hassan Saleh adalah "keyakinan akan kebenaran sesuatu, yang telah tertanam dalam lubuk hati seseorang, sehingga menjadikan kehidupan manusia bisa lebih baik lagi baik dalam sikap, ucapan dan tindakan.

Ketiga, Syari'ah dalam Islam berhubungan erat dengan amal lahir (nyata) dalam rangka mennaati semua peraturan atau hukum Allah guna mengatur hubungan antara manusia dengan tuhan dan mengatur pergaulan hidup antara sesame manuisa (Asmuni Syukri, 1983; 61). Ketetapan yang sudah mengatur hubungan manusia dengan sesame disebut muamalat.

Keyakinan merupakan dasar dari pada syari'ah. Dan syari'ah adalah hasil dari kepercayaan, sebab, perundang-undangan tanpa keimanan bagaikan bangunan yang tidak bertumpuan dan keimanan dengan tidak disertai syari'ah untuk melaksanakannya, hanyalah akan merupakan teori, ajakan, yang tidak berdaya dan berhasil. Oleh karena itu, dalam islam kita temukan suatu hubungan yang erat antara iman dan syari'ah yang mengatur segala tingkah laku, dan barang siapa yang menolak hal itu, maka mereka tidak dapat dianggap orang muslim.

Komik berasal dari bahasa Yunani yaitu komiks yang artinya sesuatu yang lucu dan berhubungan dengan komedi atau diartikan juga sebagai sebuah buku atau gambar yang terdiri dari komik strip. Komik strip merupakan cerita melalui gambar-gambar yang terpisah, dimana setiap karakter gambar berlanjutkan dengan gambar yang lain disertai dengan dialog dalam gambar. (Setiawan $G$ Sasongko, 2005: 53).

Menurut Kamus Besar Bahasa Indonesia (KBBI) komik adalah sebuah cerita yang bergambar yang terdapat didalam majalah, surat kabar, atau berbentuk buku yang umumnya mudah dipahami dan lucu, komik adalah cerita yang bertekanan pada gerak dan tindakan yang ditampilan lewat urutan gambar yang dibuat secara khas dengan paduan kata-kata dan secara umum komik adalah cerita bergambar yang ada gelembung-gelembung atau balon udara. Komik adalah suatu bentuk seni yang menggunakan gambar-gambar yang tidak bergerak yang disusun sedemikian rupa hingga membentyk jalin cerita. Komik dicetak diatas kertas dan dilengkapi dengan teks, komik dapat diterbitkan dalam berbagai bentuk mulai dari strip dalam Koran, dimuat di majalah hingga berbentuk buku (Indira Maharsi, 2011: 15).

Komik berasal dari bahasa Yunani yaitu komiks yang artinya sesuatu yang lucu dan berhubungan dengan komedi atau diartikan juga sebagai sebuah buku atau gambar yang terdiri dari komik strip. Komik strip merupakan cerita melalui 
gambar-gambar yang terpisah, dimana setiap karakter gambar berlanjutkan dengan gambar yang lain disertai dengan dialog dalam gambar. (Setiawan $G$ Sasongko, 2005: 53).

Menurut Kamus Besar Bahasa Indonesia (KBBI) komik adalah sebuah cerita yang bergambar yang terdapat didalam majalah, surat kabar, atau berbentuk buku yang umumnya mudah dipahami dan lucu, komik adalah cerita yang bertekanan pada gerak dan tindakan yang ditampilan lewat urutan gambar yang dibuat secara khas dengan paduan kata-kata dan secara umum komik adalah cerita bergambar yang ada gelembung-gelembung atau balon udara. Komik adalah suatu bentuk seni yang menggunakan gambar-gambar yang tidak bergerak yang disusun sedemikian rupa hingga membentyk jalin cerita. Komik dicetak diatas kertas dan dilengkapi dengan teks, komik dapat diterbitkan dalam berbagai bentuk mulai dari strip dalam Koran, dimuat di majalah hingga berbentuk buku (Indira Maharsi, 2011: 15).

\section{HASIL DAN PEMBAHASAN}

Penelitian ini dilakukan dalam komik yang menceritakan kehidupan sehari-hari Komik 99 Pesan Nabi merupakan salah satu karangan dari Vbi_Djenggotten. Komik ini adalah kompilasi dari seri 33 pesan nabi volume 1, 2 dan 3. Komik 99 Pesan Nabi juga adalah salah satu komik terbaik anugerah pembaca Indonesia tahun 2012. Sebuah komik berbahasa Indonesia yang didasarkan pada haditshadits nabi. Komik ini menjelaskan pesan-pesan Nabi Muhammad saw dengan penyajian berupa ilustrasi cerita keseharian masyarakat Indonesia dengan cara cara yang diceritakan dengan ringan dan lucu.

Komik ini lebih lengkap dengan berbagai nila-nilai kehidupan sehari-hari. Banyak pembelajaran yang dapatdiambil dari komik ini, selain itu komik ini juga memberikan gambaran adegan-adegan dengan sangat baik dan lebih santai. Karakter-karakter yang dibuat dalam komik mirip dengan kenyataan di kehidupan sehari-hari. Pesan dakwah yang disampaikan lebih jelas dan lebih ringan sehingga gampang untuk dipahami karena didalam komik ini menceriakan kehidupan orang-orang Indonesia. Masalah tentang peruatan jabatan, tahayul, menggosip dan lain sebagainya adalah contoh yang lumrah dilakukan di Indonesia.

Komik 99 Pesan Nabi menggunakan cara disertai gambar atau simbol-simbol dan kata-kata dalam teks yang penuh dengan tutur bahasa penuh makna.

Berdasarkan lembar koding dapat disimpulkan bahwa jumlah pesan akhlak 50 pesan aqidah 28 pesan syari'ah 34 . Jumlah yang sesuai terdapat 86 dan jumlah yang tidak sesuai terdapat 13 dengan hasil 0,86 berdasarkan rumusan analisa yaitu $\mathrm{CR}=2 \mathrm{M} /(\mathrm{N} 1+\mathrm{N} 2)$. Hasil ini bisa diterma karena jumlah ketentuannya yaitu 0,86 . 


\section{Kategorisasi Pesan Dakwah}

Berdasarkan pengelompokkan kategorisasi pesan dakwah dibagi menjadi tiga yaitu aqidah, akhlak dan syari'ah. Pengkategorian ini mengikuti pendapat dari Samsul Munir Amin (2013:90).

\section{Representasi Dakwah Kategori Akhlak}

Adapun Kategorisasi representasi dakwah yang terkumpul dari Komik 99 Pesan Nabi yang membahas tentang Akhlak sebanyak 51 pesan berdasarkan hasil table jumlah dari kategori akhlak terpuji yaitu 22 pesan, akhak tercela sebanyak 23 pesan dan akhlak kepada manusia 5 pesan. Jumlah pesan akhlak yang paling banyak adalah anjuran menjauhi akhlak tercela dan mematuhi akhlak terpuji karena hakikatnya manusia harus menjauhi larangan Allah dan mematuhi perintahnya, adapun salah satu contoh dari masing-masing kategori yaitu:

\section{Anjuran Memiliki Akblak Terpuji}

Akhlakul karimah adalah akhlak yang dibangun pertama-tama oleh hati yang tulus mencari ridho Allah baru setelah itu diikuti dengan perilaku terpuji, yang sesuai dengan anjuran islam. Diantaranya yaitu rasa saling percaya terhadap sesama umat manusia, saling membantu, saling memberi, dan lain-lain akhlak terpuji dengan niat yang suci bersih, semata-mata karena mengharapkan ridho Allah swt (Wahid Ahmadi, 2004: 33).

Sedangkan Akhlak terpuji menurut Yatimin Abdullah adalah segala tingkah laku terpuji yang merupakan tanda kesempurnaan iman seseorang kepada Allah Swt. Akhirnya yang melahirkan tingkah laku atau perbuatan baik (Yatimin Abdullah, 2006: 193).

Jumlah anjuran melakukan akhlak terpuji pada komik 99 Pesan Nabi yaitu sebanyak 22 judul, dari 50 pesan anjuran melakukan akhlak terpuji yang ada di dalam komik tersebut peneliti mengambil 4 contoh judul yang ada di dalam komik mengenai anjuran melakukan akhlak terpuji, yaitu:

\section{Porsi Makan}

Dalam komik tersebut diterangkan bahwa terdapat dua keluarga yang sedang makan di sebuah warung, keluarga yang satu makan dengan porsi banyak, sedangkan keluarga satunya lagi makan dengan porsi yang secukupnya. Pola makan sering kali dikaitkan dengan pengobatan karena makanan merupakan penentu proses metabolism pada tubuh kita, dengan mencontoh pola makan Rasulullah kita secara tidak langsung menjalani terapi pencegahan penyakit dengan makanan, hal itu jauh lebih baik dan pasti lebih murah dibanding harus berhubungan dengan obat-obatan kimia senyawa sintetik yang hakikatnya adalah racun. Seperti dalam hadis mengatakan.

Dari Abu Hurairah R.A, berkata: Rasulullah Saw. bersabda: makanan dua orang cukup untuk tiga orang. "Makanan untuk tiga orang cukup untuk empat orang”. HR. Bukhari (Vbi_Djenggotten, 2015: 175). Anjuran Menjaubi Akblak Tercela 
Akhlak tercela adalah akhlak yang harus di jauhi oleh orang-orang yang beriman. Tingkah laku atau sikap yang akan merusak pada keimanan seseorang, sikap tercela ini sering melekat pada diri seseorang dengan kebiasaan buruk yang melanggar pada aturan atau ketentuan ajaran agama. Akhlak tercela adalah sifatsifat tercela yang memunculkan serangkaian perbuatan-perbuatan yang tercela. perbuatan tercela itu adalah perbuatan yang memihak pada salah satu titik ekstrim yaitu boros, kikir, sombong, dengki dan sikap tercela lainnya (Dadan Nurulhaq dan Wildan B, 2013: 14). Seperti yang telah dijelaskan di atas dalam Komik 99 Pesan Nabi memiliki 23 judul yang mengenai akhlak tercela, salah satu contoh ialah:

Wolak Walik Jaman.

Laki-laki 1: nama eyke, Kunti... kalo malam Kuncoro

Laki-laki 2: secara gitu loh jeng, eyke kan bisa merasakan kurang baik apa coba eyke ke dia... betul, nggak jeng...

Laki-laki 1: mas ganteeeeng, akikah mawar dong di sun... yuk, ya... (menggoda sesama jenis)

Laki-laki 3: ASTAGHFIRULLAAH! BAMBANG!!!

Kita sebagai manusia harusnya mensyukuri apa yang telah Allah berikan kepada kita, jangan melebih-lebihi atau mengurang-ngurangi karena Allah akan murkah, sesungguhnya ketika Allah menciptaka apapun itu maka itu adalah hal yang paling terbaik. Seperti dalam hadits menjelaskan.

Dari Ibnu 'Abbas RA,. Katanya: Rasulullah Saw mengutuk laki-laki yang berpenampilan seperti wanita dan wanita yang berpenampilan seperti laki-laki HR. Bukhari (Vbi_Djenggotten,2015: 27).

\section{Akblak Kepada Manusia}

Akhlak kepada manusia yaitu sikap atau perbuatan yang seharusnya dilakukan oleh manusia sebagai makhluk, kepada manusia lainnya. Akhlak kepada manusia ada dua macam yaitu akhlak terpuji dan akhlak tercela. akhlak terpuji ini meliputi baik sangka rendah hati, tenggang rasa, saling menghargai dan saling menghormati sesame. Akhalak tercela ini meliputi iri hati, dengki, dendam, membicarakan kejelekan orang lain dengan tujuan menjauhkan nama baiknya, adu domba. Akhlak kepada manusia yang terdapat didalam Komik 99 Pesan Nabi ialah:

\section{Hitung-Hitungan}

Seorang anak yang menginginkan ayahnya untuk memasukkan uang di kotak infak di masjid, namun karena tergesa-gesa sang ayah pun menolak dengan alasan sebelumnya sudah memasukkan infak di masjid yang lain. Saat ayahnya mengajak ke apotik, anak tersebut ingin dibelikan alat penghitung udara untuk menghitung jumlah udara yang dihirup setiap harinya. Ayahnya menjawab kalau udara yang dihirupnya adalah gratis dari Allah. Kemudian anaknya 
mengingatkan ayahnya jika setiap hari bisa menghirup udara dengan gratis, tapi kenapa untuk bersedekah saja ayahnya perhitungan.

Diriwayatkan oleh Asma binti Abu Bakar Ash-Shiddiq, sesungguhnya dia pernah mendatangi nabi, Asma berkata,: "wahai, nabi! Saya tidak mempunyai sesuatu kecuali yang telah Az-zubair berikan kepada saya, apakah saya berdosa jika saya menyisakan sedikit untuk bersedekah dari pemberian Az-zubair itu?". Beliau menjawab, "sisishkan sedikit untuk kamu, sedekah sesuai dengan kemampuanmu, sedekah sesuai dengan kemampuan, dan jangan diingat-ingat sehingga Allah mengingat (kikir) kepadamu." HR Muslim (Vbi_Djenggotten, 2015: 412).

\section{Representasi Dakwah Kategori Syari'ah}

Representasi Pesan dakwah yang terkumpul dari Komik 99 Pesan Nabi yang membahas tentang syari'ah sebanyak 34 pesan, berdasarkan table jumlah dari kategori anjuran ibadah ada 20 judul dan muamalat ada 16 Judul.

\section{Anjuran Ibadah}

Ibadah merupakan ketaatan untuk menjauhi larangan tuhan dan untuk menjalankn perintahnya, aman yang ditunjukkan untuk berbakti kepada Allah dan dalam pelaksanaannya diatur oleh syariah (R Sutoyo Bakir dan Sigit S, 2006: 216). Salah satu anjuran ibadah yang terdapat didalam Komik 99 Pesan Nabi yang berjudul 5 Tuntunan Fitrah yaitu:

Seorang ustadz berkata kepada mad'u assalamu'alaikum tahukan anda? Apa saja lima tuntunan fitrah dalam islam itu? Pertama Khitan, kedua mencukur bulu di sekitar kemaluan, ketiga mencabut bulu ketiak, keempat memotong kuku dan kelima mencukur kumis.

Abu hurairah RA. Berkata, nabi saw bersabda: "tuntunan fitrah lima (atau lima dari tuntunan fitrah): Khitan, mencukur bulu disekitar kemaluan, mencabut bulu ketiak, memotong kuku, dan memotong (mencukur) kumis". HR. BukhariMuslim (Vbi_Djenggotten,2015: 25).

\section{Muamalat}

Muamalah adalah hubungan antar manusia dalam usaha mendapatkan alat-alat kebetulan jasmani dengan cara sebaik-baiknya sesuai dengan ajaranajaran dan tuntutan agama. Agama islam memberikan norma dan etika yang bersifat wajar dalam usaha mencar kekayaan untuk memberi kesempatan pada perkembangan hidup manusia di bidang muamalah dikemudian hari. Islam juga memberikan tuntutan supaya perkembangan itu jangan sampai menimbulkan kesempitan-kesempitan salah satu pihak dan kebebasan yang tidak semestinya kepada pihak lain.

Salah satu contoh yang terdapat didalam komik 99 Pesan Nabi yang berjudul Jaga Bertetangga yaitu. 
Disuatu desa terdapat satu warga yang sedang hajat dan pak Rt menyewa sound yang besar dan berkualitas suara yang sangat kencang dan itu sangat menggangu kenyamanan tetangganya, harusnya dalam hajat jangan terlalu berlebihan juga karena itu membuat pancingan buat orang yang mempunyai tangan jahul. Dan akhirnya sound yang dapat dari tempat sewa itupun hilang dicuri orang.

Dari Abu Hurairah RA. Bahwa bersabda: "demi Allah, tidak beriman. Demi Allah, tidak sempurna imannya. Demi Allah, tidak empurna imannya". Ketika beiau ditanya: "maksudnya siapa, ya Rasulullah?". Beliau menjawab: "orang yang tetangganya tidak merasa aman dari gangguannya". HR. BukhariMuslim (Vbi_Djenggoten, 2015: 122).

\section{Representasi Dakwah Kategori Aqidah}

Representasi dakwah yang terkumpul dari Komik 99 Pesan Nabi yang membahas tentang Aqidah sebanyak 28 pesan, berdasarkan hasil tabel jumlah dari kategori iman kepada Allah ada 16 tema, iman kepada malaikat ada 3 tema, iman kepada rasulallah ada 1 tema, iman kepada hari akhir ada 3 tema, iman kepada kitab Allah ada 4 tema, iman kepada qodo dan qadar ada 1 tema.

\section{Iman Kepada Allah}

Iman kepada Allah merupakan rukun iman yang pertama, dasar utama dan pertama bagi keimanan, keharusan untuk beriman kepada Allah, mengEsakannya, ketuhanannya, nama-namanya, dan sifat-sifatnya yang agung yang semuanya mencerminkan kesempurnaan (Yusuf Al-Qardhwi, 1986: 15). Iman merupakan kepercayaan yang meresap kedalam hati dengan penuh keyakinan, tidak tercampur dengan keragu-raguan, iman itu bukan semata-mata ucapan lidah, perbuatan, dan pengetahuan.

Berdasarkan pengertian diatas iman adalah salah satu keyakinan atau kepercayaan bahwa Allah maha Esa dan sebagai pencipta. Dalam masalah tauhid dan keimanan banyak terjadi dikalagan masyarakat pada zaman sekarang, bahkan merusak aqidah atau keyakinan seorang muslim.

Adapun judul pesan yang di tulis oleh Vbi_Djenggotten menjelaskan tentang fenomena kesyirikan dan pelanggaran tauhid. Salah satunya yaitu Tahayul

Istri: Mas, kita pulang aja ya, takutnya hujan, aku belum angkat jemuran.

Suami : Aaah tenang aja, tadi kucingku seharian hadap ke arah pintu, jadi hari ini gak bakal turun hujan.

Seorang mukmin harus taat kita tidak boleh melangah sebelum mengetahui apa ketentuan syariat dalam masalahnya. Apakah langkah yang telah kita ambil sesuai dengan ketentuan allah atau malah melenceng. Setiap langkah yang diambil dengan mendahului atau meremehkan ketentuan Allah pasti 
bersandar pada keinginan dan hawa nafsu. Sehingga ia terburu-buru untuk melangkah sesuatu yang hanya dibangun dengan prasangka dan keraguan. Mendahului ketentuan Allah hanya akan menghasilkan dua kemungkinan, entah itu berlebihan atau bahkan kurang. Maka dari itu Allah melarang keras agar kaum mukmin tidak mendahului ketentuan Allah dan Rasul-nya. Karena semua ketentuannya adalah yang terbaik dan paling tepat. Seperti dalam hadits dijelskan.

Dari Abu Hurairah R.A katanya Rasulullah Saw bersabda: "tidak ada penularan, tidak ada mayat gentayangan menjadi hantu kuburan, tidak ada binatang tertentu muncul menyebabkan hujan dan tidak ada tabu di bulan shafar H.R. Muslim (Vbi_Djenggotten,2015: 240).

Ramalan adalah prediksi mengenai peristiwa-peristiwa yang akan datang, kata ramal diambil dari bahasa arab yaitu raml artinya suatu ilmu untuk menafsir, menilik, melihat atau memprediksi nasib seseorang atau apa yang akan terjadi dimasa depan. Meramal nasib manusia, kejadian dan hal-hal lainnya sangat jelas dilarang oleh syariat islam, karena perkara hal-hal lainnya sangat jelas dilarang oleh syariat islam, karena perkara-perkara ini sangat jelas bersifat ghaib, meramal nasib manusia dan kejadian di masa depan hanya Allah lah yang tahu perkara hal yang ghaib. Dalam Qs An-Naml ayat 65:

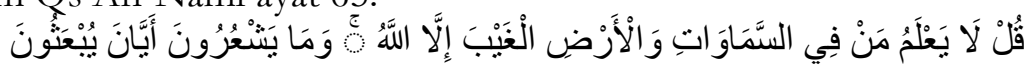

Artinya: "Tidak ada seseorang pun di langit dan di bumi yang mengetahui perkara yang ghaib, kecuali Allah. Dan mereka tidak mengetahui kapan mereka akan dibangkitkan." (An-Naml: 65).

Sebagai muslim yang baik diharapkan mempercayai perkara ghaib yang disampaikan oleh peramal ataupun dukun, jika kita sempat mempercayai haruslah cepat untuk bertaubat kepada Allah, sesungguhnya Allah akan mengampuninya Allah Maha pengampun. Dalam sebuah hadist, rasulullah bersabda, yang artinya:

"Barang siapa yang mendatangi dukun lalu dia bertanya kepadanya tentang suatu hal, maka shalatnya tidak akan diterima selama empat puluh malam"(HR Muslim no. 2230).

Pada ilustrasi yang ditulis oleh Vbi-djenggotten, ada dua orang laki-laki dan perempuan, mereka sedang asik jalan-jalan seketika perempuan mengajak pulang karena dia punya jemuran takut keburu hujan, lalu laki-laki berkata "aaaah tenang aja, tadi kucingku seharian hadap ke arah pintu, jadi hari ini gak bakal turun hujan." Pada kalimat itulah sudah terlihat bahwa si laki-laki sudah mendahului sang penguasa alam bahwa dia sudah bisa menerawang masalah tidak akan turun hujan, padahal setelah dia mengucapkan seperti itu hujan turun lebat.

Pesan yang di sampaikan pada cerita di atas bahwa kita sebagai muslim yang baik janganah mempercayai ramalan, mempercayai ramalan hukumnya 
haram, kita telah menduakan Allah Swt, kita harus meneladani pada rukun iman yang pertama yaitu iman kepada Allah, mempercaya dan menaati keesaan Allah Swt. Ramalan sama dengan ilmu sihir seperti yang dijelaskan pada hadist riwayat Abu Dawud dan Ibnu Majah "barang siapa yang mengambil ilmu perbintangan (meramal), maka ia telah mengambil bagian dari ilmu sihir".

Iman Kepada Hari Akbir

Iman kepada hari akhir artinya semua yang dikabarkan oleh Allah didalam kitabnya kepada para malaikatnya, kitab-kitabnya, kepada rasul-rasulnya, kepada hari akhir dan kepada takdir yang baik maupun yang buruk (HR. Muslim Juz 1: 8) salah satu contoh yang terdapat didalam Komik 99 Pesan nabi iyalah Dunia dan Akhirat.

Didalam komik tersebut menceriakan terdapat satu pemuda yang sedang melamun menginginkan harta berlimpah, terkenal selalu dibangga-banggakan banyak orang, tapi seketika dia tersadar dan berkata "tapi buat apa arti itu semua kalo membuatku terjerat dalam keinginan dunia, menahanku dari kesempatan untuk bisa mencium harumnya pintu surga.

Dari Mustauhid bin Syaddad RA, ia berkata: rasulullah saw. bersabda: "perbandingan antara dunia dan akhirat tidak lain seperti seseorang dari kalian yang mencelupkan jarinya ke dalam laut. Silakan dia melihat seberapa banyak air yang menempel di jarinya saat dia mencabutnya dari laut". HR. Muslim (Vbi_Djenggotten,2015: 92). Air yang melekat dijari itu adalah kehidupan dunia, sedangkan lautan luas itu adalah kehidupan akhirat.

\section{Iman Kepada Malaikat}

Iman kepada para malaikat artinya meyakini bahwa Allah Swt mempunyai malaikat yang diciptakan dari cahaya, mereka tidak bermaksiat kepada Allah Swt terhadap apa yang diperintahkan kepada mereka.

Salah satu contoh yang terdapat dalam Komik 99 Pesan Nabi ialah:

Berhubungan dengan maraknya sosial media begitu banyak orang-orang yang suka berkomentar di media sosial, suka mencela saudara sesame muslim. Dalam hadihadis diriwayatkan dari Abdullah bin Mas'ud bahkan Rasulullah bersabda, "mencela orang muslim adalah kefasikan dan membunuhnya adalah kekufuran”. HR. Bukhari (Vbi_Djenggotten,2015: 318).

Iman Kepada Rasul

Iman kepada para rasul artinya meyakini bahwa Allah Swt mengutus pada setiap umat seorang rasul yang menyeru mereka untuk menyembah Allah Swt, tidak ada sekutu baginya, dan mengingkari segala sesembahan selain Allah. Perbedaan antara nabi dan rasul adalah bahwa wahyu untuk mengamalkan syariah tersebut. Adapun rasul adalah seorang laki-laki yang diberikan wahyu kepadanya untuk mengamalkan syariat yang baru untuk disampaikan kepadanya. 
Salah satu cerita yang terdapat didalam Komik 99 Pesan Nabi yang berjudul Konflik yaitu:

Terdapat dua pemuda yang sedang bertengkar, lalu lewat seorang penjual dan mengingatkan Rasullallah saw bersabda, "janganlah kamu kafir kembali sesudahku, dimana sebagian kamu memenggal leher yang lain". Lalu merekapu tersadar dan langsung meminta ampunan.

Dari Jarir bin Abdullah Al Bajali RA. Nabi Saw berkata kepadanya ketika haji wada' (haji penghabisan), suruh tenanglah oang banyak itu!'. Kemudian beliau bersabda, "janganlah kamu kafir kembali sesudahku, dimana sebagian kamu memenggal leher yang lain”. HR. Bukhari (Vbi_Djenggotten, 2015: 251).

\section{Iman Kepada Kitab Allah}

Iman kepada hari akhir adalah meyakini bahwa Allah Swt memiliki kitabkitab yang diturunkan kepada para Rasul untuk disampaikan kepada umatnya. Kitab-kitab tersebut adalah kalamullah, yang Allah Swt bersabda dengan itu menurut hakikatnya sebagaimana yang dia kehendaki dan dengan cara yang dia kehendaki. Salah satu cerita yang terdapat didalam Komik 99 Pesan Nabi yang berjudul 3 Dosa Besar yaitu:

Ada seorang ibu yang menyuruh anaknya untuk sholat tapi si anak selalu bilang "bentar dulu mak tanggung" dan yang sedang dia kerjakan itu bukan hal yang penting (mempersekutukan Allah). Lalu ibunya menyuruh lagi si anak bilang "aaah emak, lebay bedug magrib masih 20 menit lagi (durhaka kepada orang tua). Terakhir si anak masih mengulur-ulur waktu dan berjanji tidak akan main-main lagi (sumpah Palsu).

Dari sebuah hadist riwayat muslim, dari 'Abdurrahman bin Abu Bakrah RA. Dari bapaknya, katanya: "kami berada di sisi rasulullah saw, lalu beliau bersabda: perhatikanlah! Kuberitahukan kepadamu sekalian tentang dosa-dosa besar yang paling besar (Rasulullah mengucapkannya tiga kali) seperti cerita diatas (Vbi_Djenggotten, 2015: 168).

\section{Iman Kepada Qodo dan Qadar}

Iman kepada qodo dan qadar ialah meyakini bahwa semua kebaikan dan keburukan terjadi dengan ketentuan takdir Allah. Takdir adalah ketentuan Allah yang berlaku bagi setiap makhluknya. Beriman terhadap takdir merupakan bagian dari rukun iman. Dan keimanan seseorang belum sempurna, sampai ia meyakini bahwa seemua yang menimpanya baik berupa kebaikan atau keburukan itu sudah menjadi takdir dari Allah. Salah satu cerita yang terdapat didalam Komik 99 Pesan Nabi yang berjudul Sebab Hujan.

Allah mengatur sesuatu pasti ada hikmah yang kita dapatkan, contohnya dalam cerita dikomik ini terdapat dua anak sma sedang mencari tempat teduh dan didalam halte terdapat satu keluarga yang menyalahkan hujan karena kegiatannya kehambat, beda lagi dengan dua anak muda yang mensyukuri atas 
apa yang telah allah berikan, ternyata dari sana mereka saling kenal dan akhirnya menikah.

Dari Zaid bin Khalid Al-Juhani R.A, katanya: rasulullah saw mengimami kami sholat subuh di hubaidillah, sesudah tadi malam hujan turun, setelah selesai sholat, nabi saw menghadap kepada orang banyak, lalu bersabda: "taukah anda sekalian, apa yang telah difirmankan tuhan anda?" jawab mereka, "Allah dan rasulnyalah yang lebih tahu" sabda Nabi saw, "Allah berfirman: ketika hambahambaku bangun pagi-pagi, di antaranya ada yang mukmin da nada pula yang kafir. Siapa yang berkata, hari hujan karena karunia dan rahmat allah, maka dia itu mukmin (iman) denganku, kafir dengan bintang-bintang. Dan siapa yang berkata, har hujan karena bintang ini dan bintang itu, maka ia kafir denganku, iman dengan bintang-bintang". HR. Muslim (Vbi_Djenggotten,2015: 224).

\section{Sistematika Pesan Dakwah}

Aristoteles menyarankan untuk memperkuat aspek persuasive dakwah dengan peranan text. Yaitu perbagian atau rangkaian penyusunan pesan, pesan harus dibagi ke dalam beberapa bagian yang berkaitan secara logis, susunan berikut ini mengikuti kebiasaan berpikir manusia yaitu pengantar, pernyataan, argument dan kesimpulan (Rahmat, 2002:7) sehingga pesan-pesan dapat dipahami oleh komunikan untuk kemudian memberikan timbal balik (feedback) sesuai dengan apa yang diharapkan.

\section{Pengantar}

Aristoteles mengatakan bahwa pengantar berfungsi menarik perhatian, menumbuhkan kredibilitas (erthos) dan menjelaskan tujuan. Pengantar dalam Kamus Umum Bahasa Indonesia (2007:19) pengantar diartikan sebagai kata pendahuluan.

\section{Pernyataan}

Pernyataan yang berasal dari kata "nyata" memiliki arti kata terang (terlihat dan terdengar) jelas sekali. Pernyataan bisa diartikan sebagai hal yang menyatakan atau tindakan menyertakan, pemakluman dan pemberitahuan (Suryani, 2007: 379). Adapun manfaat adanya pernyataan yaitu sebagai penjelasan dari mengapa pesan yang disampaikan penting diberikan kepada khalayak.

Argumen

Argument diartikan sebagai alasan yang dapat dipakai untuk memperkuat atau menolak suatu pendapat, pendirian atau gagasan (Suryani, 2007: 22).

Ikbtisar

Ikhtisar dapat diartikan sebagai kesimpulan dan keseluruhan pendapat yang berdasarkan pada uraian sebelumnya atau keputusan yang diperoleh berdasarkan metode berfikir dedukatif atau indukatif (Suryani, 2007:561). Adapun ikhtisar yang dimaksud dalam sisitematika ini adalah iktisar yang 
menerapkan hasil pembahasan dan keseluruhan pendapat berdasarkan uraianuraian masalah sebelumnya dalam satu pesan dakwah adapun.

Oleh karena itu dapat disimpulkan bahwa untuk dapat mencapai apa yang diinginkan penulis yaitu dengan nyampainya pesan yang telah kita ungkapkan sapai ke pembaca harus mencangkup unsur pegantar, pernyataan, argument dan kesimpulan atau ikhtisar.

Himbauan Pesan Dakwah

Proses komunikasi tentunya memiliki suatu tujuan yang ingin diucapkan dari komunikasi terhadap komunikan. tujuannya adalah untuk mempengaruhi komunikan, untuk itu komunikator dituntut untuk bisa menyentuh motif yang menggerakan atau mendorong prilaku komunikan.

Komunikasi yang efektif haruslah mengandung himbauan pesan yang jelas. Hal ini bertujuan agar dapat mempengaruhi komunikan, begitupun halnya dalam berdakwah, dalam berdakwah haruslah mengandung himbauan yang jelas, sehingga akan terjadi sebuah dakwah yang efektif. Adapun himbauan itu dapat berupa himbauan rasional, himbauan emosional, himbauan takut, himbauan ganjaran dan himbauan motivasional.

Dalam table diatas terdapat himbauan rasional sebanyak 6 pesan, himbauan emosional terdapat 4 pesan, himbauan takut terdapat 51 pesan, himbauan ganjaran terdapat 23 pesan dan himbauan motivasional terdapat 15 pesan, adapun contoh dari masing-masing himbauan sebagai berikut.

\section{Himbauan Rasional}

Himbauan Rasional merupakan proses mempengaruhi atau menyakinkan orang lain dengan pendekatan logis atau penyajian bukti-bukti. Apalabila didasarkan pada anggapan bahwa manusia merupakan makhluk rasional yang baru bereaksi pada himbauan emosional bila himbauan rasional tidak ada. Salah satu contoh yang terdapat didalam Komik 99 Pesan Nabi ialah Iya, Ini Islam:

Cerita yang terdapat didalam komik 99 Pesan Nabi adalah terdapat satu pasangan sumi istri melihat seorang yang sedang duduk disamping jalan sambil memangku anaknya yang sedang tidur, lalu seorang pasangan menyapa orang yang sedang duduk dijalan tersebut "Assalamu'alaikum apa kabar bapa?" lalu seorang yang sedang duduk disamping jalan tersebut menjawab "eh wa'alaikumsalam, alhamdulilllah, Alhamdulillah baik". Lalu dua orang tersebut memberikan makanan kepada orang yang kurang mampu tersebut. Disini menceritakan bahwa islam itu indah, saling berbagi sebagaimana dalam hadits menyebutkan.

Dari Abdullah bin Umar RA. Katanya seorang laki-laki bertanya kepada rasululah saw, katanya: "Islam yang bagaimanakah yang lebih utama?", jawab Nabi saw, "memberi makan (orang-orang miskin), mengucapkan salam kepada orang yang engkau kenal dan orang yang tidak engkau kenal". HR. Bukhari (Vbi_Djenggotten, 2015: 140). 


\section{Himbauan Emosional}

Himbauan emosional menggunakan pernyataan-pernyataan atau bahasa yang menyentuh emosi komunikate. Sudah lama diduga bahwa kebanyakan tindakan manusia lebih didasarkan kepada emosi dari pada sebagai hasil pemikiran. Tahun 1936 Harman (Jalaludin Rahmat, 2004:299) meneliti pengaruh selembaran emosional dan rasional dalam mempengaruhi prilaku politik dalam pemilihan umum. Ia menemukan bahwa pesan yang mempengaruhi prilaku politik dalam pemilihan umum. Ia menemukan bahwa pesan yang menggunakan himbauan emosional lebih berhasil daripada pesan-pesan rasional. Dengan demikian efek himbauan emosional akan kurang kuat jika topic yang dibicarakan bukan sesuatu yang baru. Salah satu contoh yang terdapat didalam Komik 99 Pesan Nabi ialah Wuahahaha:

Didalam Komik 99 Pesan Nabi terdapat cerita tiga orang yang sedang makan didalam kafe dengan makanan yang sangat banyak, sedangkan diluar kafe tersebut terdapat dua orang pemulung yang sedang menahan lapar dan sedang beristirahat karena cape. Jelas didalam islam tidak boleh makan berlebihan dan harusnya ingat bahwa diluar sana masih banyak orang-orang yang kelaparan, seperti yang dijelaskan dalam hadits:

Dari Anas RA. Ia berkata: "Rasulullah saw. pernah menyampaikan khutbah di hadapan kami, khutbah yang belum pernah kami dengar sebelumnya. Dalam khutbah tersebut beliau bersabda: "sekiranya kalian mengetahui apa yang kuketahui, niscaya kalian akan sedikit tertawa dan banyak menangis". Para sahabat pun menutupi muka mereka seraya menangis sesenggukan" HR. Bukhari-Muslim (Vbi_Djenggotten, 2015: 132).

\section{Himbauan Takut}

Himbauan takut merupakan himbauan yang mencerminkan, mengancam atau meresahkan. Beberapa penelitian menjelaskan bahwa efektivitas himbauan takut bergantung pada jenis pesan, kredibilitas komunikator, dan jenis kepribadian penerima. Salah satu contoh yang terdapat pada Komik 99 Pesan Nabi ialah Tato:

Di dalam Komik 99 Pesan Nabi menceritakan seorang suami mempersembahkan rasa cinta ke istrinya dengan membuat inisial nama istrinya. Jelas didalam Islam tidak menyarankan malah lebih ke mengharamkan perbuatan tersebut karena mendzolimi badan sendiri dengan membuat tato secara tidak langsung dia menyakiti anggota badannya sendiri. Seperti dalam hadits menyebutkan dari Ibnu 'Umar RA. Katanya: "bahwasannya Rasulullah saw mengutuk orang yang meminta rambutnya disambung pembuat tato dan yang meminta ditato. HR. Muslim (Vbi_Djenggotten,2015: 275).

Himbauan Ganjaran 
Himbauan ganjaran merupakan rujukan yang menjanjikan komunikate sesuatu yang mereka perlukan dan yang mereka inginkan. Salah satu contoh yang terdapat didalam Komik 99 Pesan Nabi ialah Istiqomah:

Terdapat cerita didalam Komik 99 Pesan Nabi ada dua orang yang sedang bekerja mengangkat bata, salah satu berkata "dikit-dikit bro biar gak kecapean" lalu lelaki satunya menjawab "kalo dikit-dikit kapan selesainya" dan lelaki berkepala pelontos itu menjawab lagi "sedikit dulu bro yang penting konsisten" lelaki bertopi menjawab lagi "aaah kelamaan bisa sampai seminggu". Dan akhirnya orang bertopi itu pun kelelahan dan menyerah. Jelas didalam islam tidak disarankan melakukan sesuatu yang berlebihan, seperti didalam hadis diriwayatkan dari 'Aisyah bahwa Rasulullah menemuinya, pada waktu itu bersamanya ada seorang wanita. Beliau bertanya, "siapakah ini?" "Aisyah menjawab, "dia adalah Fulanah". Aku menceritakan kepada beliau tentang ibadahnya yang berlebihan. Kemudian beliau bersabda, "sebaiknya engkau melakuan ibadah sesuai dengan kemampuan kalian. Demi Allah, Allah tidak akan lelah memberikan pahala karena banyaknya amalmu, justru engkau yang akan lelah. Sesungguhnya amal yang paling dicintai Allah adalah yang dilakukan secara terus menerus". HR. Bukhari (Vbi_Djenggotten, 2015: 314).

\section{Himbauan Motivasional}

Himbauan motivasi gunanya dalam mempertajam sebuah pesan dengan sebuah motivasi, jika motif menyentuh intern manusia maka akan berlangsung dengan efektif. Himbauan motivasional dapat diklasifikasikan kepada dua bagian: motif biologis dan motif psikologis. Manusia bergerak bukan saja didorong oleh keinginan biologis saja melainkan psikologisnya juga. Salah satu cerita dalam Komik 99 Pesan nabi adalah berjudul Suami Idaman:

Didalam Komik 99 Pesan Nabi menceritakan satu pasangan suami istri, seorang suaminya selalu membantu pekerjaan rumah tangga dan selalu membahagiakan istrinya. Perbuatan seperti ini sangat memotivasi buat para pasangan diluar sana supaya bisa mencontoh perbuatan yang mulia seperti ini, bahkan Rasulullah pun melakukannya seperti yang dijelaskan didalam hadits Aswad RA. Berkata bahwa ia bertanya kepada 'Aisyah, katanya: "apa yang diperbuat Nabi dalam rumah tangganya?", jawab "Aisyah, "beliau juga melakukan pekerjaan rumah tangga, menolong istri beliau. Dan apabila waktu sholat telah tiba, beliau pergi sholat”. HR. Buhari (Vbi_Djenggotten,2015: 141).

\section{PENUTUP}

Berdasarkan hasil pembahasan yang telah ditentukan berdasarkan hasil koding yang peneliti lakukan terhadap Komik 99 Pesan Nabi mengenai Representasi Dakwah dalam Komik, maka dapat disimpulkan sebagai berikut:

Berdasarkan hasil penelitian dapat diketahui bahwa pesan akhlak yang terkumpul dari Komik 99 Pesan Nabi terdapapat pesan akhlak paling banyak 
dan didalam pesan akhlak juga dibagi menjadi beberapa kategori salah satunya yaitu pesan anjuran menjauhi akhlak tercela contoh anjuran menjauhi akhla tercela yang terdapat didalam Komik 99 Pesan Nabi yang berjudul "Wolak Walik Jaman". Representasi dakwah yang termasuk kategori Syariah salah satu kategorinya yatu anjuran Ibadan contoh judul yang terdapat didalam Komik 99 Pesan Nabi "5 Tuntunan Fitrah". Representasi dakwah yag termasuk kategori Aqidah memiliki kategori pesan dakwah yang berkaitan dengan Rukun Iman yaitu Iman kepada Allah sebagai pesan yang jumlahnya paling banyak salah satu judul yang berkaitan yaitu "Tahayul".

Untuk memperkuat aspek persuasive dakwah dengan peranan text. Yaitu perbagian atau rangkaian penyusunan pesan, pesan harus dibagi ke dalam beberapa bagian yang berkaitan secara logis, susunan berikut ini mengikuti kebiasaan berpikir manusia yaitu pengantar, pernyataan, argument dan kesimpulan, beberapa judul ada yang tidak menggunakan pernyataan tiga dan argumen satu untuk sisanya seperti pengantar dan kesimpulan ada semua.

Komunikasi yang efektif haruslah mengandung himbauan pesan yang jelas. Hal ini bertujuan agar dapat mempengaruhi komunikan, begitupun halnya dalam berdakwah, dalam berdakwah haruslah mengandung himbauan yang jelas, sehingga akan terjadi sebuah dakwah yang efektif. Adapun himbauan rasional sebanyak enam adapun salah satu contoh dalam judul yang terdapat dalam Komik 99 Pesan Nabi yaitu "Ini Islam", himbauan emosional terdapat 4 pesan judul yang berkaitan "Wuahaha", himbauan takut terdapat 51 pesan judul yang berkaitan "Tato", himbauan ganjaran terdapat 23 pesan judul yang terdapat pada Komik 99 Pesan Nabi "Istiqomah" dan himbauan motivasional terdapat 15 pesan adapun judul yang berkaitan yaitu "Suami Idaman".

\section{DAFTAR PUSTAKA}

Ilyas Ismal dan Prio Hotman, 2011, Firasat Dakwah, Rekayasa Pembangunan Agama Dan Perdaban Islam, Jakarta, Kencana.

Abd Rosyad Saleh, 1986, Manajemen Dakwah Islam, Jakarta, Bulan Bintang.

Abdullah bin Abdul Aziz Al-Jibrin, 2007, Cara Mudah Memahami Aqidah sesuai Al-Quran As-sunnah dan Pemahaman Salafush Shalih, Jakarta, Pustaka At-tazkia.

Abuddin Nata, 1996, Akhlak Tasawuf, Jakarta, PT Raja Grafindo Persada. Abudin Natta, 1994, Alquran dan Hadits, Jakarta, Raja Grafindo Persada.

Aep Kusnawan, 2004, Berdakwah Melalui Tulisan, Bandung, Mujahid Press.

Aep Kusnawan, 2016, Teknik Menulis Dakwah, Bandung, Simbioasa Rekatama Media.

Asmaran As, 2007, Pengantar Studi Akhlak, Jakarta, PT Raja Grafindo Persada. 
U. Inayah, S. Anwar, \& Bahrudin

Asmuni Syukri, 1983, Dasar-Dasar Strategi Dakwah Islam, Surabaya, Al-ikhlas.

Atma Kusuma, 1990, Ensiklopedia Nasional Indonesia, Jakarta, Cipta Andi Pustaka.

E. Hassan Saleh, 2000, Study Islam Diperguruan Tinggi Pembinaan IMTAQ dan Pengembangan Wawasan, Jakarta, ISTN.

Enjang As dan Aliyudin, 2009, Dasar-Dasar Ilmu Dakwah, Bandung, Widya Pajajaran.

Eriyanto, 2011, Analisis Isi, Jakarta, Kencana Prenada Group.

Faizah dan Lalu Muchsin E, 2006, Psikologi Dakwah, Jakartah, Kencana Prenada.

Hajir Tajiri, 2015, Etika dan Estetika Dakwah (perspektif teologis, filosofis dan praktis), Bandung, Simbolisa Rekatama Media.

Hendi Suhendi, 2007, Fiqh Muamalah, Jakarta, Raja Grafindo Persada.

Indira Maharsi, 2011, Komik, Dunia Kreatif Tanpa Batas, Yogyakarta, Kata Buku.

M Subana, 2005, Dasar-Dasar Penelitan Ilmiah, Bandung, Pustaka Setia.

Marcel Danesi, 2010, Pesan, Tanda, dan Makna, Yogyakarta, Jalasutra

Mas'ud Ichsan, Abdul Qodir DKK, 1991, Kamus Istilah Pengetahuan, CV. Bintang Pelajar, Jakarta.

Moh Ali Aziz, 2009, Ilmu Dakwah, Jakarta, Fajar Interpratama Offset.

Muhammad Fathan Al-Haq, 2007, Da'wah Tak Sekedar Kata!, Bandung, Bina Biladi Press.

Nawiroh Vera, 2015, Semiotika dalam Riset Komunikasi, Bogor, Ghalia Indonesia.

Nurul Baddruttamamam, 2005, Dakwah Kolaboratif Tarmidzi Taher, Jakarta, Grafindo.

Onong Uchjana Effendy, 2011, Ilmu Komunikasi, Bandung, Remaja Rosdakarta. Samsul Munir Amin, 2013, Ilmu Dakwah, Jakarta, Amzah.

Syukriyadi Sambas, 1999, Dasar Dasar Bimbingan (Irsyad) Dalam Dakwah Islam, Bandung, Kp Hadid.

Tato Tasmara, 1987, Komunikasi Dakwah, Jakarta, Gaya media Tasmara. Wahid Saputa, 2012, Pengantar Ilmu Aktual, Jakarta, Rajagrafindo Parsoda.

Ebta Setiawan, Kbb.web.id, diposting pada tahun 2012-2018 http://kbbi.web.id/representasi diakses pada taggal 09 Juli 2018.

Wikipedia, Komik, http://id.m.wikipedia.org/wiki/komik diakses tanggal 17 mei 2018. 